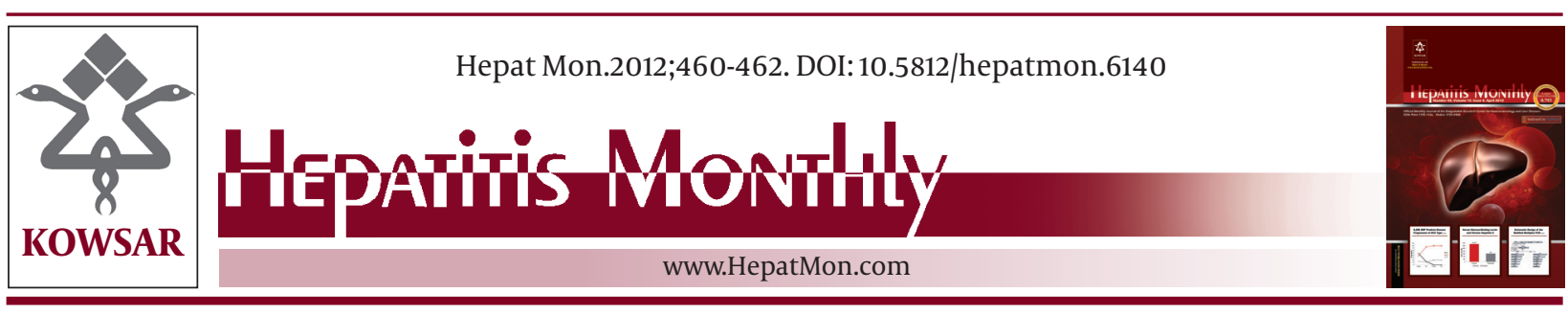

\title{
Epidemiology of Viral Hepatitis B and C Infections in Ibb City, Yemen
}

\author{
Rajesh Nivarti Gacche ${ }^{1}$, Al Mohani Sadiq Kaid ${ }^{1 *}$ \\ ${ }^{1}$ Biotechnology department, School of Life Sciences, Swami Ramanand Teerth Marathwada University, Nanded, India
}

\section{A R T I C L E I N F O}

Article type:

Short Communication

Article history:

Received: 07 Mar 2012

Revised: 30 May 2012

Accepted: 17 Jun 2012

Keywords:

Hepatitis B virus

Hepatitis C

Epidemiology

Yemen

\begin{abstract}
A B S T R A C T
Background: The global epidemic of hepatitis B and hepatitis $\mathrm{C}$ is a serious publichealth problem. Chronic hepatitis B and hepatitis $\mathrm{C}$ are among the leading causes of preventable death worldwide. World Health Organization (WHO) estimates that up to two billion people in the world have been infected with HBV; about 350 million people live with chronic HBV infection, and about 600,000 people die from HBV- related liver disease or HCC each year. The endemicity of infection is considered high in Yemen. Data for prevalence of HBsAg and HCV antibodies in Ibb city in Yemen is rare and inadequate. objectives: The study was undertaken to study the epidemiology and prevalence of viral hepatitis (HBV) and (HCV) in Ibb city, Yemen.

Patients and Methods: 554 pre-designed questionnaires and sera samples were collected in July 2010. Sera were tested for HBsAg and HCV antibodies by ELISA quantitative technique. Each individual's data were collected in a pre-designed questionnaire.

Results: The prevalence of HBV in Ibb city was $1.81 \%$, whereas, the prevalence of HCV was $1.99 \%$.

Conclusions: This study revealed low level risk of hepatitis B virus and hepatitis C virus infections. Inadequate information on the prevalence and risk determinants of viral hepatitis among the different population groups in Yemen are responsible about morbidity and mortality of HBV and HCV in Ibb city, Yemen.
\end{abstract}

Copyright $\odot 2012$ Kowsar Corp. All rights reserved.

Implication for health policy/practice/research/medical education:

It contributes in health education programs about viral hepatitis in Yemen and is useful for health policy makers.

Please cite this paper as:

Gacche RN, Kaid As. Epidemiology of Viral Hepatitis B and C Infections in Ibb City, Yemen. Hepat Mon. 2012; 460-2. DOI: 10.5812/hepatmon.6140

\section{Background}

The global epidemic of hepatitis B and hepatitis $C$ is a serious public- health problem. Chronic hepatitis B and hepatitis $\mathrm{C}$ are among the leading causes of preventable death worldwide (1). It is estimated that HBV and HCV infections cause nearly a million death cases each year. The World Health Organization (WHO) estimates that up to two billion people in the world have been infected with $\mathrm{HBV}$; about 350 million people live with chronic HBV infection, and about 600,000 people die from HBV-related liver disease or HCC each year $(2,3)$. The prevalence of

\footnotetext{
*Corresponding author: Al Mohani Sadiq Kaid, Biotechnology department, School of Life Sciences, Swami Ramanand Teerth Marathwada University, Nanded, India. Tel:+91-9765456603, E-mail: almohani06@yahoo.com

DOI:10.5812/hepatmon.6140

Copyright @2012 Kowsar Corp. All rights reserved.
}

chronic HBV infection varies geographically, from high $(>8 \%)$, intermediate $(2-7 \%)$ to low $(<2 \%)$ prevalence (4). The endemicity of infection is considered high in Yemen, where prevalence of positive HBsAg ranges from $8 \%$ to 20 $\%$, and up to $50 \%$ of the populations generally have serological evidence of previous HBV infection (5). In other studies, the prevalence of HBsAg in Yemen is $12.7 \%-18.5$ $\%$ (6). However, the prevalence of antibodies to HCV is 1.7 $\%$ in healthy volunteers (7). Most of epidemiological studies were done in different cities in Yemen, the prevalence rates of HBsAg and HCV antibodies are $10.5 \%$ and $2.3 \%$ in Sana'a, $4.75 \%$ and $0.6 \%$ in Aden, $5.6 \%$ and $0.8 \%$ in Hajah, $26.3 \%$ and $5.1 \%$ in Soqotra respectively (8). Although Ibb city is the densest populated governorate outside of Sana'a city and it has the largest Yemeni expatriates abroad, data for prevalence of HBsAg and HCV antibodies in Ibb city were rare and inadequate. 


\section{Objectives}

The main aim of this study was to determine the prevalence of HBsAg and HCV antibodies among population in Ibb city, and to determine the risk factors using HBsAg and HCV antibodies as indicators for infection.

\section{Patients and Methods}

This work is carried out within the epidemiological and laboratory field work in July 2010. 554 specimens were randomly selected by systematic random sampling of every 5th house in Ibb city. A full history was taken from each studied individual and the findings recorded in a pre-designed questionnaire. Four milliliters of whole blood were collected from each subject. Then the sera were separated. HBsAg and HCV antibodies were detected by commercial kits (One step HBsAg Test, Intec,
China) and (Rapid Anti-HCV Test, Intec, China). Positive samples were confirmed by enzyme immunoassay (EIA) for hepatitis B surface antigen and HCV antibodies with commercially kits (DRG, HBsAg, USA) and (DRG, HCV antibodies, USA). All collected data were analyzed using SPSS program.

\section{Results}

A total of 554 volunteers completed the study questionnaire and donated blood. $69.7 \%$ (386) were females. Figure 1 outlines prevalence of HBV and HCV in Ibb city; the percentages were $1.81 \%$ (10) and $1.99 \%$ (11) respectively. The percentage of HBV and HCV infections among females were $1.62 \%$ (9) and $1.81 \%$ (10) respectively, which is higher than in males. Individuals who aged between 55 - 62 years old had the highest percentage of HBV and HCV infections, which were $0.54 \%$ (3) and $0.72 \%$ (4) respec-

\begin{tabular}{|c|c|c|c|c|c|}
\hline & Patients, No. (\%) & HBsAg a Positive, No. (\%) & Pvalue & HCV ABs a , No. (\%) & Pvalue \\
\hline Gender & & & 0.142 & & 0.106 \\
\hline Male & $168(30.3)$ & $1(0.18)$ & & $1(0.18)$ & \\
\hline Female & $386(69.70$ & $9(1.62)$ & & $10(1.81)$ & \\
\hline Age group, y & & & 0.000 & & 0.000 \\
\hline$\leq 14$ & $54(9.7)$ & $00(00)$ & & $00(00)$ & \\
\hline $15-22$ & $214(38.6)$ & $2(0.36)$ & & $1(0.18)$ & \\
\hline $23-30$ & $143(25.8)$ & $1(0.18)$ & & $2(0.36)$ & \\
\hline $31-38$ & $55(9.9)$ & $00(00)$ & & $00(00)$ & \\
\hline $39-46$ & $32(5.8)$ & $1(0.18)$ & & $1(0.18)$ & \\
\hline $47-54$ & $22(4)$ & $2(0.36)$ & & $2(0.36)$ & \\
\hline $55-62$ & $20(3.6)$ & $3(0.54)$ & & $4(0.72)$ & \\
\hline $63-70$ & $9(1.6)$ & $00(00)$ & & $00(00)$ & \\
\hline$\geq 71$ & $5(0.9)$ & $1(0.18)$ & & $1(0.18)$ & \\
\hline \multicolumn{2}{|c|}{ Knowledge of viral hepatitis } & & 0.240 & & 0.306 \\
\hline Yes, I have knowledge & $410(74)$ & $6(1.09)$ & & $7(1.27)$ & \\
\hline No, I have no knowledge & $142(25.6)$ & $4(0.72)$ & & $4(0.72)$ & \\
\hline Missing value & $2(0.4)$ & - & & - & \\
\hline \multicolumn{6}{|c|}{ Source of Knowledge of viral hepatitis } \\
\hline Friends and Relatives & $89(16.1)$ & $00(00)$ & & $1(1.12)$ & \\
\hline TV & $45(8.1)$ & $00(00)$ & & $00(00)$ & \\
\hline Radio & $6(1.1)$ & $00(00)$ & & $00(00)$ & \\
\hline Newspapers & $76(13.7)$ & $1(1.32)$ & & $1(1.32)$ & \\
\hline Hospital and Clinics & $68(12.3)$ & $00(00)$ & & $1(1.47)$ & \\
\hline Others sources & $289(52.2)$ & $5(1.73)$ & & $5(1.73)$ & \\
\hline \multicolumn{2}{|c|}{ Knowledge of viral hepatitis infection } & & 0.066 & & 0.076 \\
\hline Yes, I am infected & $8(1.4)$ & $1(0.18)$ & & $1(0.18)$ & \\
\hline No, I am not infected & $261(47.1)$ & $5(0.9)$ & & $6(1.08)$ & \\
\hline I do not know & $284(51.3)$ & $4(0.72)$ & & $4(0.72)$ & \\
\hline Missing value & $1(0.2)$ & - & & - & \\
\hline
\end{tabular}




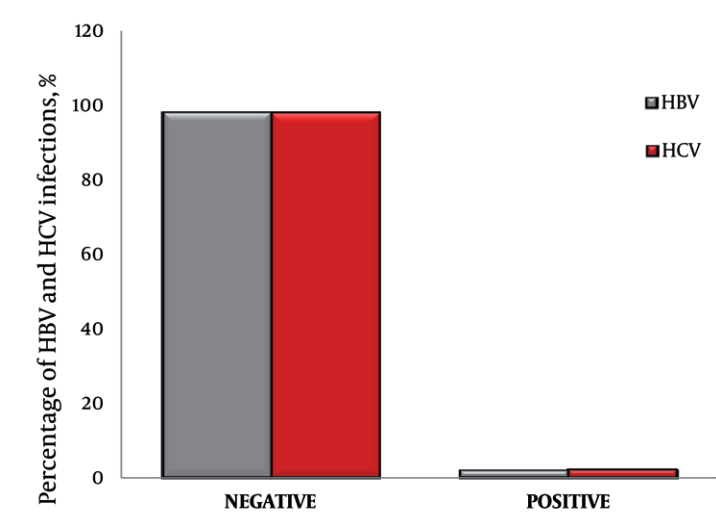

Figure 1. Shows Percentage of HBV and HCV Infections in Ibb City

tively as illustrated in Table 1. About $74 \%$ (410) of tested people had an idea about viral hepatitis and the sources of their knowledge were in schools or collages which represented $52.2 \%$ (289) of others sources. The percentages of HBV and HCV morbidity according to tested individuals among their family were $4 \%$ (4) and $21 \%$ (19) respectively, whereas, the percentage of HBV and HCV morbidity among non-family members were $10 \%$ (9) and $13 \%$ (11) respectively. The mortality of viral hepatitis was $22 \%$ (123). Out of this percentage, only $3 \%$ (4) of death contributed to HBV infection and $18 \%$ (22) to HCV infection.

\section{Discussion}

Prevalence of HBV and HCV may be different in different regions and various groups of the same community. Previous studies revealed prevalence rates of HBV as $10.5 \%$ in Sana'a, 4.75 \% in Aden, 5.6\% in Hajah, 26.3\% in Soqotra and $2.7 \%$ in Mukala. This study estimated that the prevalence of HBV exposure in the population of Ibb city was $1.81 \%$. However, previous studies revealed prevalence rates of HCV as 2.37 \% in Sana'a, 0.6\% in Aden, 0.8 \% in Hajah, and $5.1 \%$ in Soqotra. This study estimated that the prevalence of HCV exposure in the population of Ibb city was 1.99 $\%$. According to WHO, Yemen has an intermediate level, which is $2 \%-7 \%$ of $\mathrm{HBV}$ and $2.5 \%-4.9 \%$ of HCV. The decline in prevalence rate of HBV in Ibb city may be attributed to many factors, such as increased HBV vaccination that Yemen introduced universal immunization against HBV for infants and high risk groups in early 2000, which contributed to combat hepatitis B virus. In addition, Ibb city has the largest Yemeni expatriates abroad distributed in Saudi Arabia; about 500,000 and USA; about 200,000 , these countries insist that new comers should be free from viral hepatitis $\mathrm{B}$ and $\mathrm{C}$. The percentages of HBV and HCV infections among females are higher than in males, this may be cause of females number in taken samples was higher. The highest HBV and HCV infections were $0.54 \%$ and $0.72 \%$ which observed in age group 55-62. These people had variable history of exposure to HBV and HCV risk factors such as major/dental surgery or blood transfusion. This increase could indicate an accumulated risk of infection over time. In addition, the results indicated that the horizontal spread of hepatitis B virus may be of a greater importance than vertical transmission. Our study is partially in agreement with previous studies. $52.2 \%$ of tested subjects acquired their knowledge during their study in schools or collages. This indicates the weak role of health education programs in Yemen. The mortality of viral hepatitis was $22 \%$, from this percentage, only $3 \%$ of death contributed to HBV infection and $18 \%$ (22) to HCV infection. These results are similar to other studies. Inadequate information on the prevalence and risk determinants of viral hepatitis among the different population groups in Yemen are responsible about morbidity and mortality of HBV and HCV in Ibb city, Yemen.

\section{Acknowledgements}

We thank Mrs. Fatmah Hazeb for helping in Epidemiological field work and Mrs. Fadelia Alamari and Miss. Raja'a for helping in Laboratory Field work. We are very grateful to Dr. Ismail Alsabahi and Mr. Gamil Alghythi for their helpful discussions.

\section{Authors' Contribution}

None Declared.

\section{Financial Disclosure}

None Declared.

\section{Funding Support}

None Declared.

\section{References}

1. Colvin HM, Mitchell AE. Hepatitis and Liver Cancer: A National Strategy for Prevention and Control of Hepatitis B and C. Washington, DC: National Academies Press; 2010.

2. Hepatitis B. WHO; 2002; Available from: http://www.who.int/csr/ disease/hepatitis/whocdscsrlyo20022/en/.

3. Weekly epidemiological record. Journal. 2009 Date; 84(40): Available from: http://www.who.int/wer/2009/wer8440.pdf.

4. Hou J, Liu Z, Gu F. Epidemiology and Prevention of Hepatitis B Virus Infection. Int J Med Sci. 2005;2(1):50-7.

5. Al-Shamahy H. Prevalence of hepatitis B surface antigen and risk factors of $\mathrm{HBV}$ infection in a sample of healthy mothers and their infants in Sana'a, Yemen. Ann Saudi Med. 2000;20(5-6):4646.

6. Wasfi OA, Sadek NA. Prevalence of hepatitis B surface antigen and hepatitis $C$ virus antibodies among blood donors in Alexandria, Egypt. East Mediterr Health J. 2011;17(3):238-42.

7. Fallahian F, Najafi A. Epidemiology of hepatitis C in the Middle East. Saudi J Kidney Dis Transpl. 2011;22(1):1-9.

8. Bajubair MA, Elrub AA, Bather G. Hepatic viral infections in Yemen between 2000--2005. Saudi Med J. 2008;29(6):871-4. 